\title{
Genes de virulência de Helicobacter Pylori e polimorfismos gênicos do hospedeiro ligados à suscetibilidade à infecção
}

\author{
Helicobacter pylori virulence genes and host gene \\ polymorphisms linked to susceptibility to infection
}

Joice Ribeiro Lemos ${ }^{\text {I }}$

Larissa de Oliveira Rosa MarQUES ${ }^{\text {II }}$

Ana Karoline Silva Oliveira "I Xisto Sena Passos

Juliana Menara de Souza MARQUES

Milton CAMPLesi JUNioR ${ }^{1}$ Mônica Santiago Barbosa ${ }^{\text {II }}$ Antonio Márcio Teodoro Cordeiro Silva ${ }^{\text {III }}$

LuCAs Luiz de Lima SiLva ${ }^{\mathrm{I}}$ ${ }^{1}$ Universidade Paulista (UNIP), Goiânia/GO - Brasil. "Iniversidade Federal de Goiás (UFG), Goiânia/GO - Brasil. III Pontifícia Universidade Católica (PUC), Goiânia/GO - Brasil.
RESUMo Introdução: Helicobacter pylori (H. pylori) é um bacilo espiralado gram-negativo capaz de induzir inflamação persistente na mucosa gástrica com diferentes lesões, como gastrite crônica, úlcera péptica e câncer gástrico. Porém, a infecção não necessariamente induz à patogenia gastrointestinal, para isso tem-se a influência dos fatores de virulência e patogenicidade.

Objetivos: Descrever os principais genes de virulência da ilha de patogenicidade e plasticidade e os principais polimorfismos gênicos do sistema imunológico do hospedeiro e correlacioná-los com lesões causadas pela infecção por $H$. pylori.

Métodos: Trata-se de uma revisão da literatura sobre os polimorfismos gênicos do sistema imune do hospedeiro e genes de virulência ligados à suscetibilidade à infecção por $H$. pylori por meio de pesquisas, a fim de identificar evidências relevantes.

Resultados: Os genes da ilha de patogenicidade (cagPAI) são: cagA, vacA, babA, HP-NAP, cagE, iceA, cagG, virB11 e virD4; os genes da ilha de plasticidade são $d u p A, s a b A$ e oipA. Os genes do sistema imune do hospedeiro que apresentam polimorfismos e estão associados à infecção por $H$. pylori são: IL-6, IL-8, IL-1 $\beta$, TNF- $\alpha$ e IL-10. As principais doenças gastrointestinais relacionadas à $H$. pylori são: atrofia gástrica, gastrite crônica, úlcera gástrica, úlcera duodenal e carcinoma gástrico.

Conclusão: Cepas de $H$. pylori distintas apresentam genes de virulência diferentes, desencadeando resposta imune com diferentes intensidades, provocando doenças gastrointestinais diferentes.

Palavras-chave: Helicobacter pylori. Ilhas Genômicas. Patogenicidade. Virulência.

Abstract Introduction: Helicobacter pylori (H. pylori) is a gram-negative spiral bacillus capable of inducing persistent inflammation in the gastric mucosa with different lesions, such as chronic gastritis, peptic ulcer and gastric cancer. However, the infection does not necessarily induce gastrointestinal pathogenesis, for this, it has the influence of virulence and pathogenicity factors.

Objectives: The aims of this work were to describe the main virulence genes of the island of pathogenicity and plasticity and the main gene polymorphisms of the host's immune system, correlating them with lesions caused by $H$. pylori infection. 
Methods: This is a literature review on the gene polymorphisms of the host's immune system and virulence genes linked to susceptibility to $H$. pylori infection in order to identify relevant evidence.

Results: The pathogenicity island genes (cagPAI) are cagA, vacA, babA, $H P-N A P, c a g E$, ice A, cagG, virB11 and virD4; the plasticity island genes are $d u p A, s a b A$ and oipA. The host immune system genes that suffer polymorphisms and are associated with infection by $H$. pylori are IL-6, IL-8, IL-1 $\beta$, TNF- $\alpha$ and IL-10. Gastrointestinal diseases related to $H$. pylori are: gastric atrophy, chronic gastritis, gastric ulcer, duodenal ulcer and gastric carcinoma.

Conclusion: Different strains of $H$. pylori have different virulence genes, triggering immune responses with different intensities, causing different gastrointestinal diseases.

Keywords: Helicobacter pylori. Genomic Islands. PathogeniCITY. ViRULENCE.

\section{INTRODUÇÃO}

O microrganismo Helicobacter pylori foi isolado pioneiramente por Barry Marshall e Robin Warren, pesquisadores australianos, em fragmentos de biópsia da mucosa gástrica de um paciente com gastrite crônica. ${ }^{1}$ Todavia, a relação causa e efeito entre a presença da bactéria, gastrite crônica e a úlcera duodenal, só foi constatada no ano de 1985, quando Barry Marshall contraiu a infecção experimental ao ingerir um inóculo bacteriano, salientando que $H$. pylori poderia ser o agente etiológico de doenças gastrointestinais; contrapondo o pensamento habitual da época, que acreditava que nenhuma bactéria sobreviveria no estômago humano devido à alta acidez no local. ${ }^{2}$

H. pylori é uma bactéria em forma de bacilo, gram-negativa, contendo múltiplos flagelos unipolares embainhados que lhes dão mobilidade, é microaerófila e espiralada, podendo ser encontrada também na forma de coco-bacilos. ${ }^{3} \mathrm{~A}$ infecção gástrica por H. pylori deve seu êxito ao fato de a bactéria produzir enzimas tóxicas, como, lipase, urease e proteases, desequilibrando as defesas do epitélio gastrointestinal, com os fatores de aderência que proporcionam elevada capacidade de adesão à mucosa gástrica. ${ }^{3,4}$
A infecção por $H$. pylori é altamente disseminada na população mundial, entretanto, na sua maioria, assintomática, sem nenhuma manifestação clínica. Somente uma pequena porcentagem dos indivíduos infectados pelo $H$. pylori desenvolve alguma das patogenias desencadeadas pela bactéria. ${ }^{3}$ A transmissão da $H$. pylori ocorre via oral-oral, fecal-oral, por meio de alimentos e água contaminada, iatrogênica ou gastro-gástrica e, atualmente, a transmissão sexual, via anal-oral e zoonótica, tem sido propostas. ${ }^{2}$ Visto que a infecção pela bactéria não necessariamente vai induzir à patogenia gastrointestinal, tem-se a influência dos fatores de virulência e patogenicidade. As Cepas de $H$. pylori possuem variedade genotípica, esse fato se deve à heterogeneidade genética do microrganismo e essa variedade caracteriza a intensidade da resposta inflamatória e imune do hospedeiro. ${ }^{5}$

Cepas distintas de $H$. pylori possuem genomas diferentes, polimorfismos gênicos que caracterizam a intensidade da resposta inflamatória e imune do hospedeiro. ${ }^{5} \mathrm{O}$ nível da lesão deve-se aos fatores de virulência da bactéria, à resposta inflamatória da mucosa gástrica do hospedeiro e à alteração da secreção gástrica. ${ }^{6}$ 


\section{ObJetivos}

Objetiva-se descrever os principais genes de virulência que influenciam na suscetibilidade à infecção por $H$. pylori, destacando os genes das ilhas de patogenicidade e plasticidade, e os principais polimorfismos gênicos do sistema imunológico do hospedeiro e correlacioná-los com as principais lesões gastrointestinais causadas pela infecção por $H$. pylori.

\section{Metodologia}

Trata-se de uma revisão da literatura de aspecto descritivo sobre os polimorfismos gênicos do sistema imune do hospedeiro e os genes de virulência relacionados à infecção por $H$. pylori, destacando os genes da ilha de patogenicidade e plasticidade, por meio de pesquisas de investigação focada em uma questão bem definida, visando identificar e selecionar, avaliar e sintetizar as evidências relevantes disponíveis.

\section{RESUlTADOS \\ Genes de virulência}

Bactérias de cepas diferentes têm fatores de virulência e patogenicidade distintos, provocando inúmeras respostas imunes, visto que a resposta imune vai de acordo com a interação dos genes de virulência da bactéria com o sistema imunológico do hospedeiro, que também tem suas particularidades e possíveis polimorfismos gênicos, intensificando a resposta do sistema imunológico, levando assim a quadros variáveis de doenças gastrointestinais. ${ }^{7}$ Os genes que induzem resposta imune de elevada intensidade são aqueles encontrados nas ilhas de patogenicidade e plasticidade, sendo eles: cagA, cagE, vacA, babA, HP-NAP, cagG, virB11, virD4, iceA, dupA, sabA e oipA (Quadro 1).

Quadro 1. Genes de virulência de Helicobacter pylori e possíveis lesões e doenças correlacionadas.

\begin{tabular}{|c|c|}
\hline Genes de virulência & Lesões e doenças \\
$c a g A$ & Adenocarcinoma gástrico, úlcera duodenal \\
$c a g E$ & Úlcera duodenal, úlcera péptica duodenal \\
$v a c A$ & s1/m1/i1-úlcera péptica duodenal; s1/m1-gastrite crônica \\
$b a b a$ & Úlcera duodenal, adenocarcinoma gástrico \\
$H P-N A P$ & Gastrite crônica ativa, úlcera péptica \\
$c a g G$ & Gastrite crônica, úlcera duodenal, úlcera gástrica \\
$v i r B 11$ & Úlcera, gastrite atrófica \\
$v i r D 4$ & Inflamação crônica \\
$i c e A$ & iceAl-gastrite erosiva, úlcera péptica duodenal, câncer gástrico; iceA2- \\
gastrite assintomática, gastrite enantematosa \\
supA
\end{tabular}




\section{Gene $\operatorname{cag} A$}

$\mathrm{O}$ gene cagA (cytotoxin associated gene $A)$ está localizado na ilha de patogenicidade cag-PAI e codifica uma citotoxina conhecida como proteína $C a g A$, sendo considerada um antígeno altamente imunogênico. Cepas de H. pylori $\operatorname{cag} A$-positivas apresentam maior poder de virulência e induzem maior expressão das citocinas do sistema imune do hospedeiro, como, IL-8 e IL- $1 \beta$, influenciando na intensidade da resposta inflamatória. ${ }^{8,9}$

Alterações da fosforilação de tirosinas no sítio C-terminal EPIYA (Glu-Pro-Ile-Tyr-Ala) mediadas por cinases da família Src, nas vias de sinalização e transdução de sinal para o núcleo, são induzidas quando a proteína $\operatorname{CagA}$ é injetada nas células epiteliais da mucosa gástrica do hospedeiro, o que culmina em alterações morfológicas e rearranjos do citoesqueleto, estimulando a célula a se espalhar e alongar de forma idêntica à produzida pelo fator de crescimento de hepatócitos da célula hospedeira., ${ }^{9,10}$

A estrutura do gene, em foco, revela uma região 5 ' altamente conservada, porém com uma região 3 ' com número variável de sequências repetitivas, o que leva à variação do comprimento da proteína. Assim, apresenta diferentes subtipos relacionados ao número de pares de bases existentes no mesmo. Por conseguinte, há: cagA subtipo A (621-651pb), subtipo B (732-735 pb), subtipo C (525pb) e subtipo D (756 pb). Essas variações estruturais podem estar diretamente ligadas aos diferentes potenciais patogênicos da proteína codificada. As doenças mais relacionadas a essa cepa são: câncer gástrico e úlcera duodenal, pelo fato desse tipo de cepa desencadear uma resposta inflamatória intensa. ${ }^{8,9,11}$

\section{Gene cagE}

O gene cagE (cytotoxin associated gene $E)$ está localizado em cag-PAI, próximo ao gene cagA. O gene codifica uma proteína transmembrana constituinte do SST4, localizada na membrana interna do microrganismo, com função de ATPase, que fornece energia para a montagem do sistema e transporte de substâncias. Além disso, essa proteína é responsável pela indução da secreção da IL-8 nas células gástricas epiteliais do hospedeiro. ${ }^{3,12}$

Embora os outros genes da ilha de patogenicidade cag-PAI estejam ligados ao aumento da secreção de IL-8 secretada pelas células epiteliais da mucosa gástrica, o gene cagE é considerado o mais determinante. ${ }^{4}$

Entre os hospedeiros, com a infecção por $H$. pylori de cepas cagE-positivas, o distúrbio gastrointestinal predominante é a úlcera duodenal péptica (PUD) devido ao grau de intensidade da resposta inflamatória desencadeada. ${ }^{3,12}$

\section{Gene vacA}

O gene vacA (vacuolating cytotoxin A) é um fator de virulência com ampla investigação. Tal gene codifica a citotoxina vacuolizante VacA que induz múltiplas atividades celulares, entre elas, a vacuolização das células epiteliais gástricas, interrupção das funções endossomais e lisossomais, formação de canais de membrana, imunomodulação e apoptose celular. ${ }^{4,8}$

A atividade citotóxica vacuolizante de vacA é expressa por mutações nonsense, cujo padrão de heterogeneidade da sequência apresenta regiões distintas em vários alelos de diferentes cepas. A diversidade alélica de $\operatorname{Vac} A$ é formada por três regiões 
variáveis: a região do sinal (s), região média (m) e região intermediária (i). A região do sinal com dois alelos, s1 e s2, codifica o peptídeo sinal; a região média, com os alelos $\mathrm{m} 1$ e $\mathrm{m} 2$, e a região intermediária, com os alelos i1 e i2 e i3. A m1 ainda é subclassificada em mla mlb. A patogenicidade da bactéria está associada à combinação dos alelos das regiões s, m e i determinando a produção de citotoxinas vacuolizantes. ${ }^{9,13}$

A combinação entre alelos diferentes de cada região (s1, s2, i1, i2, m1, m2) dá uma capacidade variada de induzir vacuolização em células epiteliais. As cepas vacA s1 / $\mathrm{m} 1$ são vacuolizantes, assim como as cepas $v a c A s 1 / \mathrm{m} 2$. Já as cepas vacA s2 / m2 não apresentam a capacidade de formar vacúolos celulares. Segundo estudos, existe uma alta incidência de doença ulcerosa péptica e câncer gástrico em indivíduos infectados com cepas vacA positivas, que possui os alelos s1 em comparação com aqueles que abrigam cepas s2. $H$. pylori vacA positivas com subtipos $\mathrm{s} 1 / \mathrm{m} 1$ e $\mathrm{s} 1 / \mathrm{m} 2$ causam inflamação crônica severa em comparação com os outros genótipos. ${ }^{9,10,13}$

\section{Gene $b a b A$}

O gene babA (blood group antigen A) é um fator de adesão que auxilia no estabelecimento da colonização do epitélio gástrico devido à codificação da adesina $B a b A$, uma proteína de membrana. Tal proteína se liga aos antígenos do grupo sanguíneo Lewis b nas células do epitélio gástrico, o que contribui para a patogenicidade de H. pylori. ${ }^{8,13}$

Foram identificados três alelos do gene $b a b$, sendo eles: $b a b A 1, b a b A 2$ e $b a b B$. Entretanto, apenas o gene $b a b A 2$ tem capacidade de ligação ao grupo Lewis b. A expressão do $b a b A$ apresenta diversos mecanismos de regulação em níveis de tradução e transcrição. Cepas babA-positivas estão associadas aos genes de virulência cagA e vacA. Sendo assim, estão associadas com úlcera duodenal e adenocarcinoma gástrico. ${ }^{9}$

\section{Gene HP-NAP}

O gene HP-NAP (Neutrophil-Activating Protein) codifica a proteína ativadora de neutrófilos HP-NAP que contribuem para a gastrite devido à infiltração de neutrófilos na mucosa gástrica, induzindo a adesão às células endoteliais, por meio da produção de intermediários reativos de oxigênio, gerando uma resposta inflamatória de variadas intensidades. $\mathrm{O}$ gene $H P$-NAP aumenta a síntese de fator de tecido e a secreção de inibidor do ativador do plasminogênio tipo 2. HP-NAP é quimiotático para neutrófilos e representa um dos principais fatores de virulência de $H$. pylori, participando in vivo na criação de um peculiar meio de citocinas no local da infecção. Cepas de HP-NAP estão associados à gastrite crônica ativa e úlcera péptica. ${ }^{4}$

\section{Gene cagG}

O gene cagG é da ilha de patogenicidade cag-PAI. O gene cagG codifica a proteína CagG (no inglês, cytotoxin-associated gene $G$ ), que provoca aumento da secreção de IL-8, uma característica dos genes de cag-PAI, provocando intensa resposta inflamatória na mucosa gástrica do hospedeiro sempre que associado a outro gene da ilha de patogenicidade cag-PAI. ${ }^{14,15,16}$ A proteína CagG contém sequências de sinal N-terminal e, portanto, deve ser transportada para o periplasma. De acordo com alguns estudos, 
as cepas mutantes de cagG mostraram capacidade reduzida ou nenhuma capacidade de aderir às células epiteliais além de uma redução significativa na indução de IL-8. ${ }^{17}$

\section{Gene virB11}

O gene virB11 se localiza na extremidade esquerda da cag-PAI e codifica a proteína VirB11, sendo esta imprescindível para o transporte de proteínas por meio do sistema de secreção tipo IV, também exibindo atividade de ATPase. ${ }^{3} \mathrm{O}$ sistema de secreção tipo IV possibilita a translocação da proteína $\operatorname{CagA}$ para as células do epitélio gástrico. Cepas virB11-positivas foram relacionadas ao aumento da chance de desenvolvimento de úlcera e gastrite atrófica. ${ }^{3,16}$

\section{Gene virD4}

O gene virD4 codifica o sistema de secreção tipo IV, possibilitando a translocação da proteína CagA para as células do epitélio gástrico, assim como o gene virB11. Entretanto, faz a mediação da introdução do complexo de nucleoproteínas no mecanismo de transporte sem gasto de energia. A translocação da proteína CagA gera aumento de secreção de IL-8, induzindo inflamação crônica. ${ }^{3,15,16}$

\section{Gene iceA}

$O$ gene ice $A$ (induced by contact with epithelium gene) possui dois alelos genotípicos, sendo eles o iceA1 e o ice A2.,12 O iceA1, de transcrição positivamente regulada em resposta ao contato entre $H$. pylori e células endoteliais da mucosa gástrica do hospedeiro, codifica proteína com fortificada homologia a endonuclease de restrição. Tal gene é responsável pela elevação na expressão de IL-8, provocando uma inflamação aguda independente de outros genes como cagA e vacA. Os distúrbios gastrointestinais relacionados ao iceA1 são: gastrite erosiva, úlcera péptica duodenal e câncer gástrico. ${ }^{9}$ Entretanto, o iceA2 não possui homologia com proteínas conhecidas e não está significativamente associado a escores inflamatórios. Sendo assim, usualmente em pacientes iceA2-positivas ocorrem gastrite assintomática e gastrite enantematosa..$^{8,12}$

\section{Gene $\operatorname{dupA}$}

O gene dupA (duodenal ulcer promoting gene) é um fator de virulência de H. pylori localizado na ilha de plasticidade do genoma bacteriano. A presença desse gene, em cepas de $H$. pylori, eleva a infiltração de neutrófilos e a expressão de IL-8, aumentando assim o risco de úlcera duodenal. No entanto, se relaciona à redução do risco de atrofia gástrica, metaplasia intestinal e câncer gástrico. ${ }^{9,10}$ Apesar da presença do gene dupA em cepas de $H$. pylori estar associada ao aumento no risco de úlcera duodenal, tem uma característica chamada de cluster $d u p A$. Sendo assim, apenas quando o cluster dupA é completo há associação com risco de úlcera duodenal. ${ }^{10}$

Uma mutação Frameshift nos genes cria um códon de parada prematuro com presença de efeitos potencialmente consideráveis de expressão ou função da proteína $D u p A$. Cepas sem o códon de parada estão relacionadas com úlcera duodenal, câncer gástrico e gastrite. A presença de $d u p A$ sem um códon de parada foi com mais frequência observada em cepas de pacientes com DU do que em cepas daqueles com gastrite e câncer gástrico. Um $d u p A$ de tipo longo intacto pode produzir uma proteína DupA 
funcional e um $\operatorname{dupA}$ de tipo longo intacto pode ser um marcador de virulência eficaz para desfechos graves. ${ }^{9}$

\section{Gene $s a b A$}

Gene sabA (sialic acid binding adhesin) codifica a proteína $S a b A$, a qual é encontrada na membrana externa, identificada como uma adesina que reconhece os antígenos sialyl-Lewis $\mathrm{x}$ (sLex) e sialyl-Lewis a (sLea), como receptores funcionais de adesão de $H$. pylori na mucosa gástrica do hospedeiro. A codificação da adesina $S a b A$ é indutora principal do metabolismo oxidativo e componente essencial na indução da fagocitose. Assim, induz uma explosão oxidativa nas células epiteliais gástricas, causando danos oxidativos. Os distúrbios gastrointestinais associados à presença do gene $s a b A$ são: metaplasia intestinal grave, atrofia gástrica e câncer gástrico. ${ }^{3,13,18}$

\section{Gene oipA}

O gene oipA (outher inflammatory protein gene) codifica a proteína inflamatória OipA, posicionada na membrana externa e relacionada com processos inflamatórios. Pode ser um gene funcional ou não funcional, sendo que o gene funcional tem regulação por meio de um mecanismo de reparo, o slipped strand mispairing, um erro de capeamento, baseado no número de repetições dos dinucleotídeos CT na região 5' do gene. ${ }^{3,19}$

O gene oipA funcional eleva a produção e secreção de IL-8, assim aumentando a inflamação na mucosa gástrica, principalmente em pacientes com câncer gástrico. Além de induzir o aumento da infiltração de neutrófilos no epitélio gástrico, eleva a secreção de IL-8. Além do câncer gástrico, associa o gene à úlcera duodenal e gastrite. ${ }^{9}$

\section{Polimorfismos gênicos relaciona- dos ao hospedeiro}

Os polimorfismos gênicos relacionados ao hospedeiro, que influenciam na suscetibilidade à infecção por $H$. pylori, estão ligados aos genes que codificam citocinas e moléculas. Citocinas e moléculas que interferem diretamente na variação da magnitude individual da resposta inflamatória, que está associada principalmente aos distúrbios gastrointestinais. A principal via de resposta inflamatória ativada pela infecção envolve as interleucinas IL-6, IL-8, IL- $1 \beta$, IL-10 e TNF- $\alpha$ (Quadro 2)., ${ }^{4,9}$

\section{IL-6}

A citocina IL-6 é pró-inflamatória e multifuncional, atua como mediador inflamatório e regulador endócrino, além de desempenhar papel de suma importância nos mecanismos de resposta imunológica como mensageiro entre os sistemas inatos e os adaptativos. A IL-6 estimula também a produção de IFN- $\gamma$, a diferenciação, a manutenção de células $\mathrm{T}$ citotóxicas, além de promover a secreção de imunoglobulinas em células B ativadas. Níveis de IL-6 na mucosa gástrica se apresentam elevados na gastrite associada à $H$. pylori e com a erradicação da infecção esses níveis diminuem, não tendo relação direta com uma cepa específica de $H$. pylori. A citocina está envolvida na regulação de diversas funções celulares, tais como, proliferação, apoptose e angiogênese. ${ }^{8,9}$ 
Quadro2. Interleucinas codificadas pelos seus respectivos genes e possíveis lesões envolvidas.

\begin{tabular}{|c|c|c|}
\hline Interleucinas & Genótipo & Lesões \\
\hline IL-6 & $\begin{array}{l}\mathrm{C} / \mathrm{C} \\
\mathrm{C} / \mathrm{G} \\
\mathrm{G} / \mathrm{G}\end{array}$ & $\begin{array}{l}\text { Câncer gástrico, úlcera péptica duodenal } \\
\text { Úlcera gástrica, úlcera péptica duodenal } \\
\text { Úlcera gástrica, úlcera péptica duodenal }\end{array}$ \\
\hline IL-8 & $\mathrm{A} / \mathrm{T}$ & $\begin{array}{c}\text { Úlcera péptica duodenal, úlcera duodenal, úlcera } \\
\text { gástrica, atrofia gástrica, câncer gástrico } \\
\text { Úlcera duodenal, atrofia gástrica }\end{array}$ \\
\hline IL- $1 \beta$ & & $\begin{array}{c}\text { Hipercloridria, gastrite atrófica crônica, úlcera gástrica, } \\
\text { câncer gástrico }\end{array}$ \\
\hline TNF- $\alpha$ & & Úlcera gástrica, úlcera duodenal, câncer gástrico \\
\hline IL-10 & $\begin{array}{l}\text { T-819 e A-592 } \\
\text { IL-10 -592 A/A e } \\
\text { IL-8 - } 251 \mathrm{~A} / \mathrm{A}\end{array}$ & $\begin{array}{l}\text { Hipercloridria, atrofia gástrica, úlcera péptica duodenal, } \\
\text { câncer gástrico } \\
\text { Úlcera gástrica }\end{array}$ \\
\hline
\end{tabular}

Uma alteração nucleotídica, de G para C, localizada no cromossomo $7 \mathrm{p} 21$, gera três polimorfismos no gene de IL-6, influenciando no desenvolvimento de diversos distúrbios gastrointestinais. Os polimorfismos foram identificados em IL-6 -174, -572 e -597. Hospedeiros com alelo G IL-6 -174 e -572 têm produção aumentada de citocina IL-6 quando comparado com hospedeiros com genótipo $\mathrm{C} / \mathrm{C}$. Aqueles com genótipo $\mathrm{G} / \mathrm{G}$ ou portadores do alelo $\mathrm{G}$ possuem associação com o surgimento de úlcera gástrica, enquanto aqueles com genótipo $\mathrm{C} / \mathrm{C}$ associam-se ao câncer gástrico e têm também uma associação rara com a úlcera péptica duodenal em ambos os genótipos. ${ }^{8,9}$

\section{IL-8}

A IL-8 se apresenta como fator quimiotóxico para neutrófilos e linfócitos, e induz à proliferação celular, migração e angiogênese. Empreende um papel de vasta importância na patogênese das doenças induzidas por H. pylori, em que cepas cag-PAI-positivas apresentam aumento na secreção e expressão de IL-8. Implementa um papel essencial na iniciação, modulação e manutenção das respostas inflamatórias na mucosa gastrointestinal. Com o aumento de IL-8, tem a amplificação da resposta inflamatória por meio do recrutamento de neutrófilos e monócitos, resultando assim em avançado grau de gastrite. Além disso, quanto maior for a produção de IL-8 tanto maior será a resposta inflamatória, induzindo a diferentes distúrbios gastrointestinais, como úlcera gástrica, úlcera duodenal e câncer gástrico. ${ }^{4,8,9}$

Três polimorfismos gênicos foram detectados no gene: IL-8 -251A/T, -396T/G e -781C/T. Entre os quais, o SNP (polimorfismo de nucleotídeo único) na posição -251 é associado à elevação da produção de IL-8 e a mutação $\mathrm{T}$ para $\mathrm{A}$ na região promotora afeta a transcrição e secreção da quimiocina, induzindo assim a inflamação mais severa nas células epiteliais gástricas. Hospedeiros infectados por $H$. pylori, com genótipos de IL-8 -251 A/T diferentes, desenvolvem dis- 
túrbios distintos. Aqueles com genótipo A/A apresentam maior risco de desenvolver úlcera péptica duodenal, úlcera duodenal, úlcera gástrica, atrofia gástrica e câncer gástrico, enquanto os de genótipo A/T estão mais susceptíveis à úlcera duodenal e atrofia gástrica. Em contrapartida, o genótipo T/T possui menor poder de indução para os distúrbios gastrointestinais. ${ }^{8,9}$

\section{$I L-1 \beta$}

A citocina pró-inflamatória IL- $1 \beta$ é codificada pelo gene $I L-1 B$ e age como inibidora de secreção ácida gástrica. Desempenha também papel de suma importância na iniciação e amplificação da resposta inflamatória relacionada à infecção por $H$. pylori, visto que cepas com o gene cagA induzem níveis mais altos de expressão da citocina IL-1 $\beta$, como de IL-8. Foram detectados três SNP no gene caracterizados pela transição das bases T-C na posição -31 e das C-T nas posições -511 e +3954 no local de início da transcrição. ${ }^{4,9}$

Altos níveis de secreção de IL-1 estão associados à presença nas posições -511 e +3954 do alelo $\mathrm{T}$ e na posição -31 do alelo C. Em resposta à infecção por $H$. pylori os polimorfismos gênicos de IL-1 $\beta$-31, IL$1 \beta-511$ e IL-1 $\beta+3954$ relacionam-se com quadros de hipercloridria, gastrite atrófica crônica, úlcera gástrica e câncer gástrico. ${ }^{8,20}$

\section{TNF- $\alpha$}

A TNF- $\alpha$, codificada pelo $T N F-A$, que é um gene polimórfico, localizado no complexo principal de histocompatibilidade central, é mediadora das respostas contra bactérias gram-negativas como $H$. pylori.
A TNF- $a$ apresenta inúmeras funções biológicas que incluem a estimulação da expressão de moléculas de adesão nas células endoteliais, facilitando o extravasamento de neutrófilos para a mucosa; ativação de leucócitos e linfócitos-T; estimulação de citocinas por macrófagos e monócitos; e indução de apoptose. Assim como a IL-1 $\beta$ inibe a secreção de ácido gástrico, tem atribuição importante no processo infeccioso e, por conseguinte, no quadro de gastrite induzida pela $H$. pylori. $^{9}$

Inúmeros polimorfismos bi-alélicos no gene codificante da citocina TNF- $\alpha$ foram identificados, sendo eles: TNFA -308 G>A, TNFA -238 G>A, TNFA -1031 T/C, TNFA -863 C/A e TNFA -857 C/T. O haplótipo TNFA -308/-238 A/A associa-se ao aumento na produção de TNF- $\alpha$, conferindo assim o risco elevado de desenvolvimento em um quadro de câncer gástrico. Esses polimorfismos interferem, também, na atividade transcricional, o que os associa a quadros de câncer gástrico e úlcera duodenal.9,20,21 Os polimorfismos TNFA -1031/-863/-857 estão relacionados à elevada atividade do promotor transcricional, induzem elevação nos níveis de TNF- $\alpha$ nas células mononucleadas periféricas do epitélio gástrico, induzem a infiltração gástrica grave, além de serem fatores de risco independentes para quadros de úlcera gástrica e úlcera duodenal sem presença de metaplasia intestinal. ${ }^{9}$

\section{IL-10}

A citocina anti-inflamatória pleiotrópica IL-10 é produzida por células imunes ativas e inibe a produção de citocinas pró-inflamatórias, como IL-1, IL-2, IL-3, IL-6, IL- 8, IL-1B, TNF- $\alpha$, IFN- $\gamma$ e GM-CSF e in- 
duz à proliferação e diferenciação de células B. A deficiência relativa de IL-10 resulta em resposta hiperinflamatória dirigida por Th1 a H. pylori, causando maior dano na mucosa gástrica. A H. pylori pode induzir à regulação positiva de IL-10 e à supressão de resposta imune eficiente, favorecendo assim a sobrevivência de infecções e parasitas. ${ }^{8,9}$

Polimorfismos gênicos, detectados na região promotora do gene, estão associados à baixa produção de IL-10 caracterizados por transcrição no posicionamento -819 C-T e no posicionamento -592 C-A. O alelo $\mathrm{C}$ posicionado em -819 e -592 associa-se à produção elevada de IL-10, enquanto o alelo T na posição -819 e o alelo A -592 associam-se à baixa produção de IL-10. Essa baixa produção de IL-10 associada com $H$. pylori resulta no aumento da intensidade da resposta inflamatória na mucosa gástrica, hipocloridria e indução de quadros de atrofia gástrica, câncer gástrico e úlcera péptica duodenal. A existência de um efeito sinérgi- co entre IL-10 -592 A/A e IL-8 -251 A/A está associada à produção elevada de IL-8, induzindo à intensa resposta inflamatória, relacionando a um quadro de úlcera gástrica. ${ }^{8,9}$

\section{CONSIDERAÇõeS FINAIS}

Cepas diferentes de H. pylori possuem genes de virulência distintos, assim como os hospedeiros podem apresentar diferentes polimorfismos no sistema imune associados à resposta inflamatória contra $\mathrm{H}$. pylori. Essas características se correlacionam com quadros de doenças gastrointestinais de acordo com a resposta inflamatória desencadeada, ou seja, quando fatores de virulência e os polimorfismos gênicos se associam, a resposta inflamatória se intensifica expressivamente, causando danos graves à mucosa gástrica, induzindo quadros clínicos graves, como gastrite crônica, úlcera duodenal e câncer gástrico.

\section{REFERÊNCIAS}

1 Moreira AC, Niederle R. O Perigo Pode Estar no Estômago: Helicobacter pylori - Aspectos Epidemiológicos, Patológicos, de Tratamento e Preventivos 1. Rev. Context. Saúde. 2010; 10: 19: 59-66.

2. Teixeira TF, Souza IKF, Rocha RDR. Helicobacter pylori: infecção, diagnóstico laboratorial e tratamento. Rev. Interdiscip. da PUC Minas no Barreiro. 2016; 6: 12: 481-504.

3. Lima VP, Robenhorst SHB. Genes Associados à Virulência de Helicobacter Pylori. Rev. Bras. Cancerol. 2009; 55: 4: 389-96.

4. Ladeira MSP, Salvadori DMF, Rodrigues MAM. Biopatologia do Helicobacter pylori. J. Bras. Patol. e Med. Lab. 2003; 39: 4: 335-42.

5. Barbosa JA, Schinonni MI. Helicobacter pylori: Associação com o câncer gástrico e novas descobertas sobre os fatores de virulência. Rev. Ciências Médicas e Biológicas. 2011; 10: 3: 254-62.

6. Siqueira JS, Lima PSS, Barreto AS, Quintans-Júnior LJ. Aspectos Gerais nas Infecções por Helicobacter pylori Revisão. Rev. Bras. Análises Clínicas. 2007; 39: 1: 9-13.

7. Sjomina O., Pavlova J., Niv Y., Leja M. Epidemiology of Helicobacter pylori infection. Jounal John Wiley Sons Ltd. 2018; 23: 1: 1-6.

8. Vianna JS, Silva PEA, Ramis IB. Helicobacter pylori pathogenicity genes, cytokine polymorphisms and environmental factors affect the development of gastric diseases: an overview. Rev. Epidemiol. e Control. Infecção. 2016; 6: 4: 1-9. 
9. Yamaoka Y., Miftahussurur M. Helicobacter pylori virulence genes and host genetic polymorphisms as risk factors for peptic ulcer disease. Expert Rev Gastroenterol Hepatol. 2017; 9: 12: $1.535-47$.

10. Chang WL, Yeh YC, Sheu BS. The impacts of $H$. pylori virulence factors on the development of gastroduodenal diseases. J. Biomed. Sci. 2018; 25: 1: 1-9.

11. Backert S., Tegtmeyer N. Type IV Secretion and Signal Transduction of Helicobacter pylori cagA through Interactions with Host Cell Receptors. MDPI. 2017; 9: 15: 1-16.

12. Ramis IB, Fonseca TL, Moraes EP, Fernandes MS, Mendoza-Sassi R., Rodrigues O., et al. Molecular basis of pathogenicity in Helicobacter pylori clinical isolates. J. Clin. Microbiol. 2010; 48: 10: 3.776-8.

13. Dadashzadeh K., Peppelenbosch MP, Adamu AI. Helicobacter pylori Pathogenicity Factors Related to Gastric Cancer. Can. J. Gastroenterol. Hepatol. 2017; 2017: 1: 1-6.

14. Xu C., Li ZS, Tu ZX, Xu GM, Gong YF, Man XH. Distribution of cagG gene in Helicobacter pylori isolates from Chinese patients with different gastroduodenal diseases and its clinical and pathological significance. World J. Gastroenterol. 2003; 9: 10: 2.258-60.

15. Saito H., Yamaoka Y., Ishizone S., Maruta F., Sugiyama A., Graham DY, et al. Roles of virD4 and cagG genes in the cag pathogenicity island of Helicobacter pylori using a Mongolian gerbil model. Gut. 2005; 54: 5: 584-90.

16. Merino E., Flores-Encarnación M., Aguilar-Gutiérrez GR. Functional interaction and structural characteristics of unique components of Helicobacter pylori T4SS. FEBS J. 2017; 284: 21: 3.540-9.

17. Pereira ES, Albuquerque LM, Balbino VQ, Junior JS, Burbano RMR, Gomes JPP. Helicobacter pylori cagE, cagG, and cagM can be a prognostic marker for intestinal and diffuse gastric cancer. Infect Genet Evol. 2020; 84.

18. Yamaoka Y. Increasing evidence of the role of Helicobacter pylori SabA in the pathogenesis of gastroduodenal disease. J. Infect. Dev. Ctries. 2008; 2: 3: 174-81.

19. Su Y. Huang H., Huang B., Chen P., Chen C. Combination of OipA, BabA, and SabA as candidate biomarkers for predicting Helicobacter pylori - related gastric cancer. Sci Rep. 2016; 6: 36442.

20. Silva MR, Sampaio A., Almeida A., Balseiro S., Santos P., Carvalho L. Identificação Dos Polimorfismos Dos Genes IL1B, IL1RN E TNFA Na Gastrite Crónica Associada à Infecção por Helicobacter Pylori e no Carcinoma Gástrico. J Port Gastrenterol. 2008; 15: 1: 8-14.

21. Chojnacki C., Popławski T., Błońska A., Błasiak J., Romanowski M., Chojnacki, J. Expression of tryptophan hydroxylase in gastric mucosa in symptomatic and asymptomatic Helicobacter pylori infection. Arch. Med. Sci. 2019; 15: 2: 416-423.

\section{DADOS DOS AUTORES:}

\section{JoICE Ribeiro Lemos}

Biomédica pela Universidade Paulista (UNIP) - Campus Flamboyant, Goiânia/GO - Brasil. E-mail: joicelemos234@gmail.com

\section{Larissa de Oliveira Rosa Marques}

Graduanda em Biomedicina pela Universidade Federal de Goiás - UFG, Goiânia/GO - Brasil. E-mail: larissa313@gmail.com

\section{Ana Karoline Silva Oliveira}

Biomédica pela Universidade Federal de Goiás - UFG, Goiânia/GO - Brasil. E-mail: eukarolineoliveira@gmail.com 


\section{Xisto Sena Passos}

Docente do curso de Biomedicina da Universidade Paulista (UNIP) - Campus Flamboyant, Goiânia/ GO - Brasil. E-mail: xisto.passos@docente.unip.br

\section{Juliana Menara de Souza Marques}

Docente do curso de Biomedicina da Universidade Paulista (UNIP) - Campus Flamboyant, Goiânia/ GO - Brasil.E-mail: juliana.marques@docente.unip.br

\section{Milton CAmplesi Junior}

Docente do curso de Biomedicina da Universidade Paulista (UNIP) - Campus Flamboyant, Goiânia/ GO - Brasil.E-mail: milton.junior1@docente.unip.br

\section{Mônica Santiago Barbosa}

Coordenadora do Núcleo de Pesquisa da Helicobacter pylori - NEHP da Universidade Federal de Goiás, Goiânia/GO - Brasil. E-mail: santiagosant@gmail.com

\section{Antonio Márcio Teodoro Cordeiro Silva}

Docente do Curso de Medicina, Escola de Ciências Médicas, Farmacêuticas e Biomédicas (EMFB), Pontifícia Universidade Católica de Goiás, Goiânia/GO - Brasil. E-mail: marciocmed@gmail.com

\section{Lucas Luiz de Lima Silva}

Docente do curso de Biomedicina da Universidade Paulista (UNIP) - Campus Flamboyant, Goiânia/ GO - Brasil. E-mail: mailto:lucas.silva@docente.unip.br

Submetido em: 30-7-2020

Aceito em: 28-10-2020 